\title{
A xianbeiek sztyeppei jelenléte és a Xiongnu Birodalom bukása
}

A Kínától északra elterülő sztyeppe-övezetet, a kelet-nyugati irányban nagyjából a Hingan és az Altaj vonulatai közé esô, észak-déli irányban pedig a Bajkál-tó vidékétől a Kínai Nagy Falig nyúló területet ${ }^{1}$ az i. e. 3 század végétől kezdődően különböző nomád államalakulatok hajtották uralmuk alá, és alakították ki Kínával a fosztogatás és a békés kereskedés kettósségén alapuló viszonyukat. Az első ilyen nomád államalakulat, melyről tudomásunk van, a xiongnuké 匈奴, akik egy központosított törzsszövetséget hoztak létre ezen a területen. A Xiongnu Birodalom megszúnése után annak egykori területét egy másik nomád nép, a xianbei 鮮卑 kezdte el uralni. A jelen tanulmány célja, hogy megvizsgálja a Xiongnu Birodalom hanyatlásának és ezzel összefüggésben a xianbeiek felemelkedésének körülményeit, és átértékelje a xianbeiek sztyeppei uralmával kapcsolatos elképzeléseinket.

\section{A xiongnuk és a xianbeiek élőhelye, társadalmi szerkezete}

Mielőtt a xiongnuk és xianbeiek egymáshoz való bármiféle viszonyának vizsgálatába belekezdenénk, célszerú megjegyeznünk, hogy e két nép Belsô-Ázsia két egymással szomszédos, mégis sokban különböző régiójából

\footnotetext{
Ezt a területet a vonatkozó források számos különböző névvel jelölik. A kínai forrásokban gyakran találkozunk a saiwai 塞外 kifejezéssel mely „határon kívülit”-t jelent. Jellemző továbbá e területnek két, egy északi, azaz a Góbitól északra fekvő (mobei 漠北), illetve egy attól délre elterülő (monan 漠南) részre való felosztása. A nyugati és magyar nyelvú szakirodalomban gyakori a Központi-sztyeppe (Central Steppe), Mongol-sztyeppe (Mongolian Steppe), Mongólia (Mongolia, mint régió és nem mint ország), illetve egyszerúen csak sztyeppe vagy steppe megjelölések használata erre a területre. Jelen tanulmányomban a legegyszerúbb és a köznyelvben a steppénél jobban elterjedt sztyeppe szót használom, minden különösebb előtag nélkül, tudva, hogy az e tanulmány erejéig mely konkrét sztyeppére vonatkozik.
} 
származik. Ezek az eltérések pedig magyarázhatják a Kínával való viszonyaik közti különbségeket. A xiongnuk fó bázisterülete a sztyeppe, nagyjából a mai Mongólia és a Belsô-Mongólia autonóm terület középső és nyugati része volt. A xianbeiek elődei a donghuk 東胡, azaz „keleti barbárok”; mint ahogy kínai elnevezésük is erre utal, a xiongnuktól keletre, a Hingan-hegység környékén, Mandzsúria nyugati, a sztyeppe keleti részén éltek. ${ }^{2}$ A xiongnuk és a xianbeiek társadalmi szerkezete jelentôs eltéréseket mutat. A xianbeiek vezetőinek pozíciója a kezdetekben nem öröklődött, erre csak a későbbiekben akad példa, és akkor sem válik teljesen általánossá. Társadalmukat törzsek ( $b u$ 部) alkották, melyek élére képességeik, rátermettségük alapján, három évre törzsfőtt választottak. Ezeket a törzsfóket a kínai krónikák darenként 大人, azaz „nagy ember”-ként említik. A törzsek kisebb, néhány családot számláló egységekből, úgynevezett yiluókból 邑落álltak. Ezek élére is a törzsekéhez hasonló módon vezetóket (shuai 師) választottak. ${ }^{3}$ A törzsek szintje feletti vezetó pozíció, a több törzset összefogó államalakulat nem volt jellemző a xianbeieknél. Ha ki is alakult ilyen, az csak rövid ideig maradt fenn, és a törzsek ez alatt az idő alatt is jóval nagyobb autonómiát élveztek, mint a Xiongnu Birodalom törzsei.

\section{A Xiongnu Birodalom és a xianbei egység}

A Xiongnu Birodalom i. e. 209-tól bizonyos nézetek szerint i. sz. 155-ig, a xianbei Tanshihuai 檀石槐 törzsszövetségének megalakulásáig állt fenn. A sztyeppe történetére vonatkozó szakirodalomban a xiongnukhoz és a sztyeppét egyesítő későbbi nomád népekhez - türkökhöz, ujgurokhoz -

\footnotetext{
Holocombe 2013: 4.

3 Ma 1962: 112-29, Lin 1989: 19-21. A yiluók több családot magukba foglaló közösségek voltak. Valószínúleg a törzsek méretéhez hasonlóan a yiluóké is széles skálán mozoghatott. Túl keveset tudunk a yiluóról ahhoz, hogy megfelelő magyar terminussal helyettesítsük. Talán a nemzetség vagy a nagycsalád fogalma felelhet meg leginkább a yiluónak. Hasonlóképpen a $b u$ fogalma sem jelent teljes bizonyossággal és szigorú értelemben véve törzset (a törzs és nemzetség fogalmainak problematikájáról Belsô-Ázsiában lásd Ecsedy 1979: 165-216), de mind a magyar, mind a nemzetközi szakirodalomban meglehetósen elterjedt a $b u$ törzsként, illetve tribe-ként való fordítása, s az egyszerúség kedvéért most ettől nem térünk el.
} 
képest a xianbeiek története kevesebb figyelmet kap. Ez bizonyos szempontból érthetô is, hiszen a xianbeiek nem hoztak létre az említett népekéhez fogható birodalmat. A témában alapvető kézikönyvnek számító The Cambridge History of Early Inner Asia például nem is szentel külön fejezetet a xianbeieknek. Ebben a kötetben Yü említi csak a xianbeieket, röviden kitérve a sztyeppe Tanshihuai alatti egyesítésére a xiongnukról írt fejezete végén. ${ }^{4}$ Golden An Introduction to the History of Turkic Peoples címú múvének a xianbeiek történetét és nyelvét röviden tárgyaló fejezetében megemlít ugyan egy korábbi törzsfót is, név szerint Qizhijiant 其至鞬, de elsősorban Tanshihuai törzsszövetségére koncentrál, megjegyezve, hogy mikor Tanshihuai 155-ben elfoglalta a xiongnuk egykori területeit, azok elmenekültek. ${ }^{5}$ Vásáry István a Régi Belsó-Ázsia történetében a sztyeppei xianbeiek története kapcsán csak Tanshihuai törzsszövetségét említi, és szintén a 155-ös évhez köti a Xiongnu Birodalom bukását és a xianbeiek felemelkedését. ${ }^{6}$

A továbbiakban ennek az évszámnak a Xiongnu Birodalom végére és a xianbei hatalomátvételre, politikai jelenlétük kezdetére való vonatkoztathatóságát, illetve a hatalomátvétel fogalmának alkalmazhatóságát vizsgálom és kérdőjelezem meg. Ezekkel összefüggésben pedig a xianbeiek sztyeppe feletti uralmának átértékelésére teszek javaslatot.

A Xiongnu Birodalom a sztyeppe törzseinek erősen központosított szövetségén alapult, melynek az élén a shanyu (vagy chanyu) 單于 állt. A shanyu közvetítői szerepet töltött be Kína és a sztyeppei törzsek között. Kizárólagos jogot formált a Kínával való közvetlen kapcsolattartásra. Elvben ő döntött a fosztogató hadjáratok indításáról, és az azok beszüntetésével kapcsolatos, Kínával való egyezkedés is kizárólag aző jogkörébe tartozott. ${ }^{7}$ A fosztogatások

4 Yü 2008a: 149. Meg kell jegyeznünk, hogy Yü (2008b: 436-445) a Cambridge History of China első, a Qin- és Han-dinasztiákról szóló kötetében részletesebben szól a xianbeiekről és a velük közeli rokon wuhuanokról is.

5 Golden, 1992: 69-70.

6 Vásáry 2003: 45.

7 Jó okunk van feltételezni, hogy a shanyu nem minden esetben volt képes megakadályozni, hogy az alárendelt törzsfő́k a jóváhagyása, esetleg tudta nélkül fosztogassanak Kína határvidékein. Az egyik ilyen eset i. e. 176-ban történt, amikor az egyik nyugati törzsfő a shanyu és a kínai császár között érvényben lévő békeegyezmény ellenére betör Shang 上 helyőrségbe, és megszállja az Ordoszt (Di Cosmo 2004: 224). 
és a Kínával kötött egyezmények révén szerzett javak törzsek közti szétosztásával volt képes megtartani őket a szövetségben. ${ }^{8}$ A törzsszövetség legfőbb gyenge pontja az öröklési rendszer, a lineáris és laterális öröklési rend nehéz összeegyeztethetősége volt. ${ }^{9}$ Az ebből fakadó, hatalmi eliten belüli megosztottság, az, hogy a birodalom két alkalommal is - egymással ellenséges déli, azaz Kínának behódolt, illetve önállóságát megőrző, északi részekre szakadt, jelentősen megkönnyítette a Han-dinasztia (Han chao 漢朝, i. e. 206 - i. sz. 220) és szövetségesei (köztük a déli xiongnuk) dolgát az északi xiongnuk elleni harcokban.

A témával foglalkozó szakirodalom egyöntetúen egyetért, és nekünk is egyet kell értenünk abban, hogy xiongnuk után a xianbeiek uralták a sztyeppét, de ôk nem hoztak létre olyan központosított hatalmon alapuló törzszszövetséget, mint elődeik, ha egyáltalán beszélhetünk itt a xiongnukról mint elődökről. Hogy miként került a sztyeppe a xianbeiek uralma alá, azt Vásáry István a következőképp fogalmazza meg: „A szienpej vagy szienpi [xianbei] elnevezés az északi hiungnukkal [xiongnukkal] kapcsolatban fordult elő, mint annak a törzsszövetségnek a neve, amely Kr. u. 155 körül véget vetett a hiungnuk birodalmának északon." Pár sorral lejjebb, szintén a xianbeiekre vonatkozóan így fogalmaz: „A hiungnukat sokszor nyugtalanították támadásaikkal, de csak Kr. u. 155 körül tudták a hiungnukat végleg maguk alá gyưrni, s ezzel végrehajtották a nagy hatalmi oorségváltást Kelet-Belső-Ázsiában." 10

A következőkben megvizsgáljuk, hogy a xianbeiek 155 körül valóban véget vetettek-e az északi xiongnuk birodalmának, maguk alá gyưrték-e a xiongnukat, és hogy beszélhetünk-e „hatalmi őrségváltásról” a xiongnuk és xianbeiek viszonylatában. A kérdésfeltevést a tárgyalt korszakra és népekre vonatkozó forrásaink és a fenti megállapítások közötti ellentmondások indokolják.

\footnotetext{
$8 \quad$ Barfield 1981: 52, 58-59.

9 A Xiongnu Birodalom részletes elemzéseit lásd Barfield 1981, 1992: 32-84, Scheidel 2010, Kradin 2011.

10 Vásáry 2003: 45.
} 
Barfield „Hsien-pi »Empire«-t”, vagyis „Xianbei »Birodalmat«” említ ${ }^{11}$ könyvének, a korszakot tárgyaló alfejezete címében, az idézőjel használatával arra utalva, hogy a Xiongnu Birodalom bukása után „úgy illenék”, hogy egy másik hasonló államalakulat, egy birodalom vegye át annak a helyét, mégsem ez történik. Vásáry megállapítja, hogy a „szienpik birodalma sohasem érte el az egységesülésnek és összeforrottságnak azt az állapotát, amely a hiungnukra volt jellemzó birodalmuk fénykorában". ${ }^{12}$ Barfield hasonlóan vélekedik, és megjegyzi, hogy a xianbeieknek csak egy alkalommal és csak igen rövid időre sikerült egyesíteniük a sztyeppét. Ez Tanshihuai uralkodása (155-180) alatt következett be, és halálával az egység meg is szúnt. ${ }^{13}$ Valamelyest érthető tehát, hogy Tanshihuai törzsszövetsége, mely leginkább megközelítette a politikai egységnek azt az állapotát, amit a Xiongnu Birodalomnál láthattunk, a hatalmat a xiongnuktól átvevo, őket „maga alá gyưrő” és a következő nomád birodalmat létrehozó „ôrségváltó” színében tûnik fel. Ez a látásmód feltételezi azt, hogy egy újabb belsô-ázsiai nép korszaka akkor veszi kezdetét, amikor az egy törzsszövetség keretében egyesíti az egész sztyeppét. Az őket megelőző nomád birodalom bukását pedig kényelmes ilyen módon közvetlenül ez elé az egységesítés elé igazítani. Az azonban, hogy a xianbei egység 155-ben jött létre, természetesen nem jelenti feltétlenül azt, hogy a Xiongnu Birodalom vagy a xiongnuk sztyeppe feletti uralma csakis ugyanebben az évben érhetett véget. Ahogy látni fogjuk, ez minden valószínúség szerint nem is így történt.

\section{A xiongnuk és a keleti barbárok}

A fentebb említett problémák megértéséhez elengedhetetlen az előzmények legalább vázlatos ismerete. Ezért a következőkben a xiongnuk és xianbeiek, valamint a xianbeiekkel szoros rokonságban álló wuhuanok 烏桓 egymással és Kínával való viszonyának fontosabb történéseiről adok áttekintést.

\footnotetext{
11 Barfield 1992: 85.

12 Vásáry 2003: 45.

13 Barfield 1992: 85.
} 
Amikor i. e. 209-ben a xiongnu Modun shanyu 冒頓單于 apja meggyilkolásával magához ragadja a hatalmat, a keleti barbárok a xiongnukkal szemben jelentős erőt képviselnek. A Shiji 史記 ezt a következóképpen fogalmazza meg:

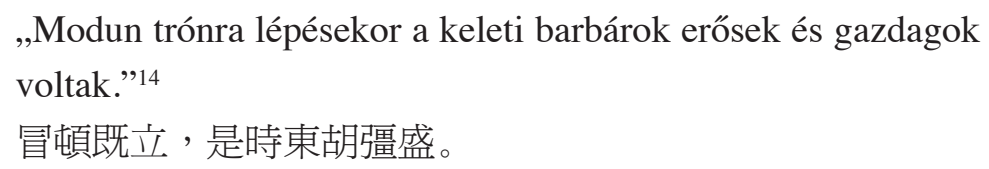

Ebből talán túlzás lenne azt a következtetést levonni, hogy a xiongnuk ekkor a keleti barbárok alávetettjei lettek volna, de a Modun hatalomra kerülését követố események sejtetik, hogy a két nép kapcsolatában a keleti barbároké lehetett a domináns szerep..$^{15}$ Amikor a keleti barbárok értesültek Modun cselekedeteiről és hatalomra kerüléséról, követet küldtek hozzá, és egyik legjobb lovát kérték tőle, ajándék gyanánt. Egyértelmú céljuk volt ezzel, hogy felmérjék a xiongnuk erejét. Modun - tanácsadói véleményével szembe menve - teljesítette keleti szomszédai kérését, akik azt természetesen a gyengeség és a tőlük való félelem jeleként értelmezték. Ezért bátorkodtak újabb követséget küldve a shanyu egyik ágyasát elkérni. Miután azt is megkapták, magabiztosan készülttek fel a xiongnuk lerohanására, és egy utolsó követséget is küldtek egy, a kettejük országát elválasztó sivatagos terület átengedését követelve. Modun tanácsadói közül néhányan azt javasolták, hogy a shanyu ezúttal is adja meg a keleti barbároknak, amit kérnek, hiszen

14 Shiji 110/7 (Xiongnu liezhuan 匈奴列傳). A könnyebbség kedvéért a kínai krónikák (Hanshu 漢書, Hou Hanshu 後漢書, Qian Hanji 前漢紀, Sanguozhi 三國志, Shiji 史記) passzusaira a Chinese Text Project nevú internetes adatbázis (http://ctext.org/) számozása szerint hivatkozom. Itt a fejezetek kisebb passzusokra osztva érhetők el, ami a szövegben való tájékozódást jelentősen megkönnyíti. A / jel utáni szám ezeknek a passzusoknak a számát jelöli. Az első szám a fejezet száma, ami megegyezik az egyéb kiadások számozásával.

15 Yü (2008b: 436) szerint a keleti barbárok az i.e. 3. század végén, közvetlenül Modun hatalomra jutása előtt hatalmuk csúcsán álltak, gyakran támadták meg a xiongnukat nyugaton. Modun aztán ezt a tendenciát fordította meg. Di Cosmo (2004: 187) szerint miután Meng Tian 蒙恬, a Qin-dinasztia hadvezére i. e. 215-ben elúzte a xiongnukat az Ordosz vidékéről, a xiongnuk válságos helyzetbe kerültek. Az Ordosszal fontos gazdasági bázisterületet veszítettek el, és kénytelenek voltak északabbra húzódni. A meggyengült xiongnuk így nyugaton a yuezhik, keleten pedig a keleti barbárok támadásainak célpontjává váltak. 
az említett területnek nem volt nagy értéke. Modun kivégeztette ezeket a tanácsadókat (csakúgy, mint a korábban vele ellenvéleményen lévőket), és támadást indított a keleti barbárok ellen, akik egyáltalán nem számítottak erre a lépésre. A xiongnuk megölték a donghuk uralkodóját, népét uralmuk alá hajtották, jószágaikat, vagyonukat elvették. ${ }^{16}$ Vásáry az esemény kapcsán megjegyzi: „Mikor Maotun, az első nagy hiungnu uralkodó legy̋̋zte a keleti barbárokat, kínai nevükön tunghukat, akik a mai Mandzsúria területén éltek, helyüket a szienpik és vuhuanok foglalták el.”17

A kínai források ismeretében muszáj pontosítanunk ezt a megfogalmazást. A Hou Hanshu 後漢書 a wuhuanokkal és a xianbeiekkel kapcsolatban a következóket írja:

„A wuhuanok eredetileg keleti barbárok (donghu). A Han-dinasztia elején, mikor a xiongnu Modun elpusztította országukat, maradékaik a Wuhuan-hegyhez menekültek. Innen kapták nevüket." 18

烏桓者, 本東胡也。漢初, 匈奴冒頓滅其國, 餘類保烏桓 山, 因以爲號焉。

„Axianbeiek szintén a keleti barbárok (donghu) egy csoportja, akik tőlük leválva a Xianbei-hegynél éltek, és arról kapták nevüket.”19 鮮卑者, 亦東胡之支也, 別依鮮卑山, 故因號焉。

A Moduntól elszenvedett vereség után tehát a keleti barbárok két csoportra válva elhagyták korábbi lakhelyüket, és a Xianbei- és Wuhuan-hegyek vidékére menekültek. A két csoportot ettól kezdve nevezik a források xianbeinek és wuhuannak, az említett hegyek után. Szó sincs tehát arról, hogy a legyőzött keleti barbárok helyét két másik nép foglalta volna el.

16 Shiji 110/7,Hanshu 漢書 64 (Xiongnu zhuan 1. 匈奴轉上), Shang/8, Qian Hanji 前漢紀 11/2 (Xiaowu Huangdi ji er 孝武皇帝紀二).

17 Vásáry 2003: 45.

18 Hou Hanshu 88/1 (Wuhuan xianbei liezhuan 鳥桓鮮卑列傳). A bao 保 „ơriz, védelmez” jelentésú szó a Han-kori és későbbi történeti múvekben gyakran jelenti, hogy „átteszi székhelyét”, ,odamegy és ott berendezkedik”.

19 Hоu Hanshu 88/14. 
Az említett hegyek hollétét teljes bizonyossággal nem tudhatjuk, az viszont szinte biztos, hogy azok a keleti barbárok korábbi lakhelyétől valamelyest délebbre estek. ${ }^{20} \mathrm{~A}$ két hely közül a wuhuanoké esett közelebb a kínai határhoz. ${ }^{21} \mathrm{~A}$ keleti barbárok tehát nem vándoroltak messzire korábbi lakhelyüktől, és ezáltal nem is szabadultak meg a xiongnuk fenyegetéseitől, ha egyáltalán ez lehetett a céljuk. Elképzelhetô, hogy ezek az emberek pusztán a közvetlen életveszélytől, esetleges lemészárlásuk elől menekültek, a tágabb régióból való távozás gondolata vagy reménye nélkül. A wuhuanok és feltehetóen a xianbeiek is ${ }^{22}$ a vereségtôl kezdve a xiongnuk alávetettjei, évenkénti adóval és katonai szolgálattal tartoztak nekik. Így a xiongnuk Kína elleni fosztogató hadjárataiban is rendre részt vettek. ${ }^{23}$

A következő majdnem kilenc évtizedben a xiongnuk xianbeiekkel és wuhuanokkal való viszonyát illetően jelentős változás nem történik, legalábbis tudomásunk ilyesmiról nincs.

\section{A ,xiongnuk jobb és bal karjának levágása”}

I. e. 128-119 között Han Wudi 漢武帝 parancsára nagy hadjárat-sorozat indul a xiongnuk ellen, melynek utolsó felvonása a Huo Qubing 霍去病 által vezetett 119-es északi hadjárat. A hadjárat sikereinek következtében a xiong$n u k$ ideiglenesen elhagyják a Góbitól délre esô területeket. Ekkor a Han-dinasztia a wuhuanokat közvetlenül a kínai határ közelébe költözteti azzal a céllal, hogy órizzék a határt, és folyamatosan tartsák szemmel a xiong$n u \mathrm{k}$ mozgását. ${ }^{24}$ Ezzel a lépéssel a dinasztia egy időre megfosztja a xiongnukat keleti szövetségeseitől, ahogy a kínai krónikák fogalmaznak, „levágják a xiongnuk bal karját” (zhan xiongnu zuobi 斬匈奴左臂). A Nyugati területek

20 Lin (1989: 28-35) feltevései szerint a Wuhuan-hegy a mai Belső-Mongólia Chifeng 赤峰 városától északnyugatra, a Xianbei-hegy pedig szintén Belsô-Mongóliában, Tongliao 通辽 várostól keletre lehetett.

21 Részletesebben lásd Holocombe 2013: 4-5.

22 Barfield 1992: 85, Yü 2008a: 126.

23 Hou Hanshu 88/3.

24 Hou Hanshu 88/3. 
feletti ellenőrzésüket, azaz ,jobb karjukat” (youbi 右臂) a xiongnuk már az első két hadjárat során, az i. e. 120-as években elveszítették.

A Han-dinasztia a wuhuanok felügyeletére kinevez egy „wuhuan védnök parancsnokot" ( $h u$ wuhuan xiaowei 戶烏桓校尉), hogy megakadályozza a xiongnuk és a wuhuanok esetleges szövetkezését. A wuhuanok szolgálatuk fejében védelemben és rendszeres ellátmányban részesülnek. Ez a helyzet egészen az időszámításunk szerinti első évtizedig nem is változik lényegesen, csak annyiban, hogy a kínai protektorátus alatt erőre kapó wuhuanok már az i. e. 70-es évek legelején - bosszúból az i. e. 209-es vereségért - feltúrják a xiongnu shanyuk sírhelyét, és Kína határvidékeit is elkezdik fosztogatni. Közvetlenül a xiongnuk büntetőhadjárata után, i. e. 78-ban a kínai csapatok is megverik őket, és több mint 6000 embert mészárolnak le közülük. I. e. 52ben a Xiongnu Birodalom két részre szakad. A xiongnuk egy része Huhanye 呼韓邪 shanyu vezetésével behódol Kínának. Más részük Huhanye fivére, Zhizhi 郅支 vezetésével egy ideig még uralja a sztyeppe Góbitól északra esô részét, majd késôbb, Kína és a Huhanye vezette déli xiongnuk elől nyugatra vándorol. Zhizhi i. e. 36-ban Szogdiánában veszti életét a Han-ház és a Nyugati területek városállamai által intézett közös támadásban. Huhanye behódolását követően a wuhuanok is behódolnak Kínának, és a következő fél évszázad békében, különösebb esemény nélkül telik. ${ }^{25}$

\section{Wang Mang 王莽 interregnuma és a nomád szövetségesek elvesztése}

I. sz. 9-ben az addig régensként uralkodó Wang Mang egy új dinasztia, a Xin 新 (9-23) császáraként lép trónra, és az addiginál kevésbé rugalmas, szigorúbb politikát folytat a sztyeppei nomádokkal szemben. A Han-dinasztiával elentétben ô például a xiongnu shanyut nem ismeri el a kínai császárral egyenrangú félként. Továbbá megtiltja a wuhuanoknak, hogy kereskedjenek és adót fizessenek a xiongnuknak. Ebből feltételezhetjük, ekkorra a xiongnuk

25 Lin 1990: 38, Hou Hanshu 88/4. 
bizonyos mértékben visszaszerezték uralmukat a wuhuanok felett, különben nem lett volna értelme a tiltásnak. ${ }^{26}$ Mikor a wuhuanok a tiltásra hivatkozva megtagadják az adófizetést, a xiongnuk wuhuan nőket, gyermekeket és öregeket ejtenek foglyul, és váltságdíjat követelnek értük. A wuhuanok a váltságdíjjal küldöttséget indítanak a shanyuhöz, aki nem csak, hogy nem adja vissza a foglyokat, de még a küldöttséget is foglyul ejti. Végül csak Wang Mang közbenjárására hajlandó elengedni az összes foglyot. Az incidens után a xiongnuk és Wang Mang összecsapásra készülnek. A wuhuanok a foglyok visszaszerzése miatt lekötelezve érzik magukat Wang Mangnak, így eleinte hajlandóak részt venni a xiongnuk elleni harcban. Wang Mang a wuhuan harcosokat (és dinglingeket 丁零 is) Dai helyőrségben (Dai jun 代郡) állomásoztatja, készülődve az összecsapásra. A wuhuanok feleségeit és gyermekeit túszként fogva tartja, nehogy a harcosok dezertáljanak vagy a xiongnuk oldalára álljanak. A hosszú hadi készültség és a kedvezőtlen körülmények miatt a wuhuanok elégedetlenkedni, majd szökdösni és fosztogatni kezdenek. Wang Mang válaszul kivégezteti hozzátartozóikat. Ezzel Wang Mang és a wuhuanok közti szövetség végleg felbomlik, a xiongnuk pedig a helyzetet kihasználva könnyúszerrel veszik rá a wuhuanokat a velük való szövetségre. ${ }^{27}$

Wang Mang uralmának a Sárga-folyó alsó szakaszának áradásai és egyéb természeti katasztrófák által gerjesztett felkelés, a vörösszemöldökúek felkelése (chimei zhi luan 赤眉之亂) vet véget. 23-ban Gengshi 更始 császár (ur. 23-25) trónra lépésével megtörténik a Han-dinasztia restaurációja, ám az ekkor még meglehetősen gyenge lábakon áll. A Nyugati területek feletti befolyását Kína ekkorra teljesen elvesztette, míg a xiongnuk Huduershi 呼 都而尸 shanyu vezetésével visszaszerezték területeik egy jó részét északon, illetve egykori szövetségeseiket mind nyugaton, mind pedig keleten. Így a wuhuanokat és xianbeieket ismét a xiongnuk szövetségében találjuk. ${ }^{28}$

26 Yü (2008: 437) szerint a wuhuan-védnökség nem volt képes maradéktalanul ellátni a feladatát, és nem tudta mindig megakadályozni, hogy a xiongnuk továbbra is alávetettjeikként kezeljék a wuhuanokat.

27 Hou Hanshu 88/5.

28 Yü 2008b: 142. 


\section{A Keleti Han-dinasztia (23-220) és a szövetségesek visszaszerzése}

A Keleti Han-dinasztia első évtizedeiben tehát a xiongnuk Kína gyengeségének köszönhetően visszaszerzik a wuhuanok és xianbeiek feletti uralmukat, és külön-külön, de egymással szövetségben fosztogatják Kína határvidékeit. Változások ezen a téren csak a 40-es évek közepétől kezdődnek. I. sz. 45ben Liaodong kormányzója (taishou 太守), Zhai Rong 祭肜 olyan vereséget mér a xianbeiekre, hogy azután nem merészkednek a határ közelébe. Ezután Zhai Rong szövetséget ajánlj a xianbeiek ambiciózus vezetőjének, Pianhenek 偏何. Ettől kezdve a xianbeiek a dinasztia szolgálatában a xiongnuk ellen harcolnak. Minden levágott xiongnu fejért cserébe jutalmat kapnak, a xiongnuk pedig az egész északi határ mentéról Liaodongba mennek kinevezéseket és jutalmakat átvenni. ${ }^{29}$ Ez az első alkalom, hogy a xianbeiek mint szövetségesek jelennek meg a Han-dinasztia oldalán. Éppen ekkoriban, 46-ban újabb öröklési vita osztja meg a xiongnukat, ráadásul természeti katasztrófák - sáskajárás és aszály - is súlyosbítják a helyzetüket. Kihasználva megosztottságukat és gyengeségüket, immár a wuhuanok is hirtelen szembefordulnak velük, és kelet felól megtámadják ôket. Ekkor a xiongnuk északra menekülnek, s a Kína határaihoz közelebb eső részeket a wuhuanok és xianbeiek tartják uralmuk alatt. 48-ban a xiongnuknak az újabb öröklési vitában alul maradt része Bi 比 shanyu vezetésével úgy dönt, hogy Kína határain belülre költözik. A Xiongnu Birodalom északi és déli részekre válik. 49-ben Guangwu 光武 császár (ur. 25-57) bőséges pénz-, selyem- és brokátajándékokkal csábítja a wuhuanokat Kínával való szövetségre. A wuhuanok a határ menti tíz helyőrség (Liaodong 遼東, Liaoxi 遼西, Youbeiping 右北本, Yuyang 漁陽, Guangyang 光陽, Shanggu 上谷 Dai 代, Yanmen 雁門, Taiyuan 太原 és Shuofang 朔方) területére költöznek, a dinasztiától élelem és ruha formájában juttatást kapnak, melyekért cserébe a határt ôrzik és védik az északi xiongnukkal és a xianbeiek Kínával éppen ellenséges törzseivel szemben.$^{30}$ Ezekben az időkben a dinasztia természetesen a déli xiongnukat is felhasználja az északiak elleni harcaihoz.

29 Sanguozhi 三國志 30/2.

30 Hou Hanshu 88/8. 
Ekkor még a wuhuanoknak is volt egy jelentős csoportjuk, akik a határ túloldalán maradtak, nem léptek egyezségre Guangwu császárral. Ők a Chishan 赤山, azaz a „Vörös-hegy” környékén élő wuhuanok - gyakran betörnek Shangguba. Zhai Rong ellenük is hadba küldi Pianhet, aki 58 ôszén támadást indít ellenük, és szétveri ôket. A chishani wuhuanok maradékai ezzel elveszítik fó bázisterületüket, és ôk is behódolnak Kínának. ${ }^{31}$

45-58 között tehát Kína a maga oldalára állította a wuhuanokat, a xianbeiek jelentôs részét és a xiongnuk nagyjából felét. Ezek közül a déli xiongnuk és a wuhuanok költöztek Kína határain belülre, a xianbeiek többsége a határokon kívül maradva lazább szálakkal kötódött a dinasztiához.

\section{Összefogás az északi xiongnuk ellen és a xianbeiek felemelkedése}

I. sz. 73-76 között a Han-dinasztia lényegében visszaszerzi az északi xiongnuktól a Nyugati területek (Xiyu 西域) városállamai feletti befolyását. ${ }^{32}$ A 80-as években nagyszámú északi xiongnu pártol át szomszédos népekhez, wuhuanokhoz, xianbeiekhez, dinglingekhez és a déli xiongnukhoz is. Barfield szerint ennek Punu 蒲奴, az északi shanyu 83-ra datálható halála lehet az oka. ${ }^{33}$ Ugyanakkor nyilvánvaló, hogy a Nyugati területek feletti befolyásuk elvesztése igencsak meggyengítette az északi xiongnuk pozícióját, ami minden bizonnyal jelentős szerepet játszott ebben a folyamatban. 83-ban 37000 északi xiongnu vándorolt délre. A wuhuanok, xianbeiek, dinglingek, qiangok 芫 és déli xiongnuk eközben folyamatosan támadták az északi xiongnukat, és a Han-dinasztia ellenük indított hadjárataiban is részt vesznek ezek a népek. 87-ben a xianbeiek egyedül óriási vereséget mérnek az északi xiongnukra, és megölik Youliu 優留 shanyut. A vereség hatására 58 északi xiongnu törzs, körülbelül 200000 ember keres menedéket Kínában, és telepszik le Yunzhong 雲中, Wuyuan 五原, Shuofang 朔方 és Beidi 北地

\footnotetext{
31 Hou Hanshu 88/16.

32 Yü 2008a: 146-147.

33 Barfield 1992: 79.
} 
területein, tehát a déli xiongnuk között. ${ }^{34} 89-91$ között a kínaiak több nagy csapást mérnek a pusztulás szélére sodródott északi xiongnuk maradékaira. A shanyu 87-ben először az Altajba, onnan 91-ben az Ili-folyó völgyébe, aztán még nyugatabbra menekül, teljesen elhagyva ezzel a sztyeppét. Ekkor a xianbeiek elfoglalják az északi xiongnuk korábbi területeit. A még mindig ott maradt xiongnuk, mintegy 10000 ,sátornyi” (zhang 帳) ember átáll a xianbeiekhez, akik ettól jelentősen megerősödnek. ${ }^{35}$ Barfield szerint az északi xiongnuk 87-ig, a xianbeiektől elszenvedett óriási vereségig voltak a meghatározó erő a sztyeppén. ${ }^{36}$ Zhou és Yü az északi shanyu elmenekülésének évére, 91-re datálja a Xiongnu Birodalom bukását. ${ }^{37}$ Tény, hogy ezektől az évektôl kezdődően nem beszélhetünk xiongnu dominanciáról a sztyeppén.

A felvázolt események ismeretében nagy pontatlanság volna azt állítani, hogy az északi xiongnuk sztyeppe feletti uralmának a xianbeiek vetettek véget, bár szerepük ebben kétségkívül nem volt elhanyagolható. A folyamat a Han-dinasztia megerősödésével, a wuhuanok és xianbeiek szövetségének elnyerésével, a 40-es évek végén kezdődött. A xiongnuk 46-tól kiéleződő megosztottsága, majd a 48-50 között lezajló kettészakadása a dinasztia szempontjából éppen kedvező időben történt, s valószínúleg jóval többet nyomott a latba, mint a wuhuanok és a xianbeiek szövetsége. Ezek a veszteségek tették csak igazán lehetôvé azt, hogy a 70-es években az egyre nagyobb hatalmú Han-dinasztia visszaszerezze az északi xiongnuktól a Nyugati területek feletti befolyást is. Ezt követóen Kína és az egykor a xiongnuk szövetségében álló népek együttes támadássorozata hozta meg az eredményt.

94-ben érdekes fordulat történik. A 87-es vereség után Kínának behódolt északi xiongnuk nem hajlandóak alávetni magukat a déli shanyunek, saját vezetốt választanak Fenghou 逢侯 személyében, és nagy pusztítások közepette (postaállomásokat gyújtanak fel és hivatalnokokat mészárolnak le) visszatérnek északra, s a szokásokhoz híven egy keleti és egy nyugati részre

34 Fenghou történetét 94-117-ig lásd Hou Hanshu 87/29 (Nan xiongnu liezhuan 南匈奴列傳).

35 Lin 1986: 109, Yü 2008a: 147-149, Gardiner és Crespigny 1977: 4-5, Hou Hanshu 88/17, Sanguozhi 三國志 30/2.

36 Barfield 1992: 87.

37 Zhou 2015: 5, Yü 2008a: 149. A körülményekrôl lásd még Holocombe 2013: 7. 
osztják régi-új szállásterületüket. Itt azonban nem sokáig van maradásuk, hiszen az északiak területeit már három évvel korábban elfoglaló xianbeiek, a dinglingek és a déli xiongnuk is folyamatosan támadják óket, ami miatt sokuk már 96-tól kezdődően, először a nyugati, de aztán a keleti területről is visszaszivárog a déli xiongnukhoz.

A helyzet tarthatatlanságát belátva Fenghou először 104-ben, majd egy évre rá követséget küldött Kínába, és engedélyt kért a visszatérésre. Az udvar ajándékokkal viszonozta a látogatást, de érdemleges válaszra nem méltatta az új északi shanyut. Fenghou számára így egyetlen lehetôség maradt hatalma megerósítésére, a Nyugati területek feletti befolyás megszerzése. 107-ben egy évtizedre ez sikerül is neki, és a xiongnuk a nyugati államok hadaival kiegészülve be-betörnek Kínába. 117-ben azonban xianbeiek megverik Fenghout, emberei átállnak a xianbeiekhez, ő maga pedig 118-ban alig több mint száz maradék emberével dél felé indul, hogy Kínában kérjen menedéket. Az udvar ez alkalommal befogadja, és - hogy a későbbiekben ne okozzon gondot - a távoli Yingchuanba 穎川 (ma Henan 河南 tartomány) költözteti. ${ }^{38}$

\section{A xianbeiek 91-155 között}

Fenghou kísérlete a xiongnu hatalom restaurálására a sztyeppén hamar kudarcot vallott, melyben jelentós szerepe volt az északi xiongnuk egykori területeit már elfoglaló xianbeieknek. Ettől az eseménytől kezdődően a Hou Hanshu és a Sanguozhi 三國志 kizárólag a xianbeiek fosztogatásairól tudósít, az elóbbi jóval részletesebben. ${ }^{39}$ Szükségtelen most kitérnünk az összes fosztogató hadjárat felsorolására, ${ }^{40}$ viszont mindenképpen meg kell említenünk két egyéb eseményt ebből az időszakból. Yü szerint 110-körül, Schreiber szerint 107-113 között egy Yanliyang 燕荔陽 nevú xianbei törzsfó

38 Hou Hanshu 87/39-45.

39 Az érintett időszak eseményeit a Hou Hanshu 88/17-23 tárgyalja.

40 A Hou Hanshuban rögzített fosztogatások történetének német nyelvú fordítását évszámokkal lásd Schreiber 1947: 172-182. 
behódol Kínának és Ningcheng 甯城, azaz a wuhuan védnök állomáshelye környékére költözik. Ekkor 120 yiluo vezetője küld túszokat Ningchengbe, ahol úgynevezett „barbár piac” (hushi 胡市) nyílik a nomádok és a kínaiak közti kereskedésre. Ezután a xianbeiek hol fellázadnak, hol újra behódolnak Kínának, harcolnak a xiongnukkal és a wuhuanokkal. ${ }^{41}$ Nem kizárt, hogy 117-ben éppen ezek a xianbeiek azok, akik megverik a Nyugati területek felól Kínát háborgató Fenghout.

121-ben Liaoxiből két másik xianbei vezető - Wulun 烏倫 és Qizhijian hódol be Kínának. Wulun a wang 王, Qizhijian pedig az alacsonyabb hou 侯 címet kapja a dinasztiától. Még ugyanebben az évben Qizhijian fellázad, és fosztogatások hosszú sorozatába kezd. Nemcsak a kínaiakat, de a déli xiongnukat is több alkalommal támadja, akik 133-ban indítanak hadjáratot ellene, kevés sikerrel. Később Daiból is indul egy hasonló sikertelen támadás. Nem sokkal később Qizhijian meghal, és a xianbeiek fosztogatásai megritkulnak. ${ }^{42}$

Ezekben az évtizedekben a sztyeppe felől, tehát kizárólag a xianbeiek fosztogatásairól értesülünk. A Han-dinasztia a wuhuanok és déli xiongnuk segítségével igyekszik visszaverni ezeket a támadásokat. ${ }^{43}$ Északi xiongnukról Fenghou óta nem hallunk, xiongnu uralomról a sztyeppén, 87-91 óta nem beszélhetünk. Ezért meglepő az a minden bizonnyal a 130-as évek elejére vonatkozó következő megjegyzés, amelyet a Hou Hanshuban találunk:

„Huan 桓 császár idejében élt a xianbei Tanshihuai 檀石槐. Apja Touluhou 投鹿侯 volt, aki háromévnyi katonai szolgálat után, melyet a xiongnuknál töltött, hazatért. Felesége közben otthon gyermeket szült. Touluhout ez meglepte, s a gyermeket meg akarta ölni."

桓帝時, 鮮卑檀石槐者, 其父投鹿侯、初從匈奴軍三年, 其妻在家生子。投鹿侯歸, 怪欲殺之。 ${ }^{44}$

41 Yü 2008b: 444, Schreiber 1947: 174, Hou Hanshu 88/18.

42 Hou Hanshu 88/20-23, Schreiber 1947: 183, Gardiner és Crespigny 1977: 7-8.

43 Yü 2008b: 444.

44 Hои Hanshu 88/24. Tanshihuai történetének elemzését lásd Gardiner és Crespigny 1977: 7-8. 
Barfield, bár nem hivatkozik erre a megjegyzésre, csakis egyedül erre alapozhatja azt a megállapítását, miszerint bár 87-ben a xiongnu dominanciának a sztyeppén vége, egészen 130-ig voltak xianbei törzsek, melyek katonai szolgálatot teljesítettek a xiongnuk részére. ${ }^{45}$

A Touluhou távolléte alatt született gyermeket, Tanshihuait anyai nagyszülei nevelték fel, s később, 155-körül, 23 éves korában egy xianbei törzsszövetség élén egyesítette a sztyeppét. A fenti kínai megjegyzés az egyetlen, mely arra engedhet következtetni, hogy a sztyeppe xiongnu korszaka Touluhou idején még tart, majd Tanshihuai-jal zárul, a xianbei időszak pedig az utóbbival kezdődik. Bár a szóban forgó megjegyzés kétségtelenül „nem illik a képbe”, túl kevés ahhoz, hogy az egészet átrajzoljuk. Hiba lenne Touluhou xiongnuknál töltött katonai szolgálata alapján azt gondolnunk, hogy a xianbeiek még ezekben az években is a xiongnuk alávetettjei lettek volna. Előfordulhatott ilyesmi kisebb közösségek egymáshoz való viszonyában. Például egy-egy megmaradt vagy a xianbeiek uralmától időlegesen függetlenedett, erőre kapott xiongnu törzs alávethetett elszigeteltebb, védtelenebb xianbei yiluókat, vagy ejthettek foglyul xianbei embereket. A 130-as évek tájékáról Kínát éró xiongnu támadásokról már nem hallunk. Azt, hogy a sztyeppén a xianbei, xiongnu, dingling stb. törzsek ekkortájt pontosan milyen viszonyban vannak egymással, nem tudjuk. Nem zárhatjuk ki, hogy ezek alkalmanként harcban álltak egymással, és korábban megvert törzsek tagjait újabb harcaikban való részvételre kötelezték. A Kínát éró támadásokból eközben az látszik, hogy ekkor már a xianbeiek a sztyeppe urai.

\section{Tanshihuai törzsszövetsége és Kebineng kísérlete az újraegyesítésre}

A Sanguozhi a következóképpen vázolja a sztyeppe Tanshihuai alatti egyesítését:

45 $\quad$ Barfield 1992: 87. 
„Keletről és nyugatról a törzsfók mind csatlakoztak hozzá. Katonái és lovai mind igen erősek voltak. Délen fosztogatták Han határait, északon visszaverték a dinglingeket, keleten megállították a fuyu 夫餘 népet, nyugaton pedig a wusunokat 烏孫 támadták. Teljes mértékben birtokba vették a xiongnuk egykori területeit." ${ }^{46}$

東西部大人皆歸焉。兵馬甚盛, 南鈔漢邊, 北拒丁令, 東 却夫餘, 西擊烏孫, 盡據匈奴故地。

A Hou Hanshu is hasonlóan fogalmazza meg ugyanezeket ${ }^{47}$ A kínai krónikák sem Tanshihuai-jal kapcsolatban, sem pedig a 155 körüli évekből $1^{48}$ nem említenek olyat, hogy xiongnuk menekültek volna el a sztyeppéről. Tanshihuai 156-tól kezdődóen folyamatosan indította fosztogató hadjáratait Kínába. 167-ben Huan 桓 császár (ur. 147-167) heqin 和親 egyezmény megkötését ajánlja neki. Három évszázaddal korábban, az i. e. 198-128-ig terjedő időszakban ilyen egyezmény szabályozta Kína és a xiongnuk viszonyát. Ennek értelmében a shanyu ígéretet tett, hogy felhagy a fosztogatásokkal, cserébe a kínaiak évente meghatározott mennyiségú aranyat, selymet, bort és rizst küldtek a shanyunek, továbbá minden shanyu kínai hercegnőt kapott feleségül ${ }^{49}$ Az egyezmény érelmében a kínai császár és a shanyu egyenrangú diplomáciai felek voltak, a két birodalom közti határ pedig a Nagy Fal mentén húzódott. A xiongnuk később sorozatosan megszegték az egyezményt, és újabb fosztogatásaikkal kényszerítették a dinasztiát a shanyunek járó javak mennyiségének növelésére. Tanshihuai azonban visszautasítja az ajánlatot, és csak még gyakrabban fosztogatja Kína határvidékeit.

A xiongnu shanyu hatalma erósen központosított volt; mint a sztyeppe törzsei és Kína közti kizárólagos közvetítő a szövetségébe tartozó törzseket a Kínától szerzet javak szétosztása révén volt képes maga mellett tartani. A xianbeieknél viszont a hatalom megszerzése és megtartása leginkább

46 Sanguozhi 三國志 30/2.

47 Hou Hanshu 88/24.

48 Itt a Yongxing 永興 (153-154), és Yongshou 永壽 (155-158) uralkodási érák jöhetnek szóba.

49 Lin 1986: 50. 
a személyes rátermettség bizonyításával, folyamatos hadjáratokkal volt lehetséges. A vezető pozíció öröklésének - a xiongnukkal ellentétben - náluk nem voltak erős hagyományai. A xianbei törzsszövetséget alkotó törzsek is jóval nagyobb autonómiával rendelkeztek, mint a xiongnu birodalmat alkotók, s így a törzsszövetség vezetője nem sajátíthatta ki magának a Kínával való közvetlen kommunikáció kizárólagos jogát. Ezért Tanshihuai ellenérdekelt volt a xiongnuk számára korábban kedvező békeegyezmény megkötésében. ${ }^{50} \mathrm{~A}$ xianbei fosztogatások így csak akkor mérséklődnek, amikor Tanshihuai 180/181-ben, 45 éves korában meghal. Pozícióját ugyan fia, Helian 和 連 formálisan örökli, ám ôt embereinek fele szinte azonnal elhagyja, majd az egész törzsszövetség nagyon hamar darabokra hullik..$^{51}$

Az ezt követő két évtizedben nagyobb xianbei törzsfók, köztük Tanshihuai leszármazottai közötti harcokról értesülünk.$^{52}$ Ezekben a harcokban, a 200-as évek elején túnik fel egy alacsony származású xianbei törzsfó, Kebineng 軻比 能. 220-ban a Han-dinasztia véget ér, és Cao Cao 曹操 észak-kínai hadúr fia, Cao Pi 曹丕 a Wei-dinasztia 魏 Wen 文 császáraként (220-226) ül a trónra. Kebineng a Wei-jel való jó kapcsolatai révén megerősödik, a 230-as évekre a többi törzsfő́t maga mellé állítva egyesíti a sztyeppe Góbitól délre eső (monan 漠南) részét, és elkezdi fosztogatni Bing tartományt (Bing zhou 并州). 234-ben Bingból kínai csapatok indulnak Kebineng ellen, de nagy vereséget szenvednek. A fó hadvezér elesik, a csapatok teljesen megsemmisülnek. ${ }^{53}$ 235-ben You 幽 tartomány kormányzója (cishi 刺史), Wang Xiong 王雄 javaslatára Ming 明 császár (ur. 227-239) egy követnek álcázott merénylőt küld a xianbeiek közé, aki leszúrja Kebinenget. Kebineng halála után a xianbeiek közt megszúnik az egység. Gyengébb csoportjaik behódolnak Weinek, az erősebbek távolra menekülnek. ${ }^{54}$ Kebineng kísérlete, hogy egyesítse a sztyeppét, így kudarcot vallott. Halála után, csakúgy, mint Tanshihuai halála után, törzsszövetsége szinte azonnal széthullik.

\footnotetext{
Barfield 1992: 88-89.

51 Gardiner és Crespigny (1977: 38) a 180-as évek néhány fosztogatásáról úgy véli, hogy azok jó eséllyel még Heliannek tulajdoníthatók.

52 Bővebben lásd Gardiner és Crespigny 1977: 39-40.

53 Ma 1962: 191.

54 Sanguozhi 三國志 30/2.
} 


\section{Konklúzió}

Modun hatalomra jutásának idején a xianbeiek és wuhuanok elődei, a keleti barbárok (donghuk) jelentős erôt képviseltek a sztyeppe keleti perifériáján. Mivel a kínai krónikák uralkodójuk (wang) elpusztítását említik, nem zárható ki, hogy ebben az időben politikai egység, törzsek felett álló vezetés jellemezte társadalmukat. A későbbiekben a xianbeiek egészen a Keleti Han-dinasztia idejéig távol maradtak Kínától, míg déli szomszédaik és közeli rokonaik, a wuhuanok már Han Wudi idejében szövetségre léptek a Han-dinasztiával. ${ }^{55}$ Ekkor még a határ külső részén ôrzik azt a xiongnukkal és a xianbeiekkel szemben. Wang Mang interregnumának második felében és az azt követő bő két évtizedben visszarendeződés figyelhető meg. A Han Wudi hadjáratai előtti időkhöz hasonlóan a xianbeiek és wuhuanok ismét szövetségre lépnek a xiongnukkal, és fosztogatják a kínai határvidéket.

Az i. sz. 1. évszázad közepe táján a Xiongnu Birodalom két részre szakadása, a wuhuanok beköltözése Kína határain belülre , továbbá a xianbeiek Kínával való szövetsége hatalmas érvágás az északi xiongnuknak. Az 50-es évektől kezdődően az északi xiongnuk már nem egyedüli urai a sztyeppének, hiszen annak keleti és délkeleti részét már a xianbeiek tartják ellenőrzésük alatt. A 70-es években a Han-dinasztia visszaszerzi az északi xiongnuktól a Nyugati területek legfontosabb városállamai feletti ellenőrzést. Ez az északi xiongnuk bukásának közvetlen előzménye, hiszen ennek a veszteségnek a hatására az utolsó szövetségeseik is ellenük fordulnak. A 80-as évek során a kínaiak és az északi xiongnuk egykori szövetségesei - a déli xiongnuk, xianbeiek, dinglingek, qiangok és a Nyugati területeken fekvő városállamok - hadjáratsorozatai pusztítják el az északi xiongnuk már régóta hanyatló birodalmát. Igaz, ezeknek a hadjáratoknak a sorában a xianbeiek 87-es hadjárata talán mind közül a legeredményesebb, mégis túlzás lenne azt állítani, hogy a xianbeiek támadások hosszú sorozata után „maguk alá gyưrték” a xiongnukat. A 87-es és 91-es vereségeket követóen óriási számban csatlakoztak északi xiongnuk a déliekhez, illetve a xianbeiekhez. Ez utóbbiak ekkor elfoglalták a xiongnuk egykori területeit, és hamarosan ők kezdték el háborgatni Kína határvidékeit. ${ }^{56}$

55 Yü 2008b: 436, Barfield 1992: 85.

56 Yü 2008b: 443. 
A xianbeiek sem ekkor, sem később nem hoztak létre olyan, a shanyu központosított hatalmán alapuló törzsszövetséget, mint előzőleg a xiongnuk. A xianbei hatalomátvétel kérdését illetôen Barfield megállapítása túnik helytállónak. Szerinte az északi xiongnuk bukása nem egy xianbei birodalom felemelkedésének az eredménye volt, hanem a xiongnuk hanyatlása tette lehetôvé a xianbeiek felemelkedését. ${ }^{57}$ Mint azt láthattuk, a keleti barbárok már Modun idejében törekedtek a nyugati irányú terjeszkedésre. Az északi shanyu menekülésével és a xiongnuk sztyeppei uralmának végével ennek a terjeszkedésnek az útjából gördült el az akadály. Az egykori keleti barbárok egy része, a délebbre élő wuhuanok Kína határain belülre költöztek, így a sztyeppét a xianbeiek vették birtokba. Ami a xianbeiek sztyeppei politikai létezését tekintve a legközelebb állt a Xiongnu Birodalomhoz, az Tanshihuai rövid életû törzsszövetsége volt.

Fontos megjegyeznünk, hogy a xianbeiek sztyeppe feletti dominanciája már jó hatvan évvel Tanshihuai előtt elkezdődött, és a törzsszövetség széthullásával sem ért véget. Első alkalommal Qizhijian esetében kezdődhetett el egy törzsszövetség kialakulásának a folyamata, de csakúgy, mint később Kebinengnél, ez a vezetô korai halálával megtorpant. Tanshihuai véghezviszi a sztyeppe gyakorlatilag összes nomád törzsének egyesítését, de múve aztán az ő szintén korai halálával megint csak darabjaira hullik. A xianbeiek sztyeppei jelenlétének alapvetóen széttagolt jellege ezután sem változik. Ezért véleményem szerint nem Tanshihuai törzsszövetségének megalakulása az, ami új fejezetet nyit a sztyeppe történetében, hanem a xiongnuk uralmának vége, amit az i. sz. 90 körüli évekre kell datálnunk. Ettól kezdve a sztyeppe teljesen más képet mutat, mint a xiongnuk idején. Nincsenek jobb és bal „karjai”, azaz keleti és nyugati szövetségesei, és a határvidékek elleni fosztogatások sem vezetnek heqin egyezmény megkötéséhez. Amikor a xianbeiek sztyeppei történetének xiongnukéra leginkább emlékeztető szakaszával, Tanshihuai törzsszövetségével jellemezzük a xianbeiek politikai létezését, akkor nem teszünk mást, mint hogy a xiongnukéhoz mérjük a xianbeiek történelmi teljesítményét. Ezzel szemben a xianbeiek politikai

57 $\quad$ Barfield 1992: 87. 
létezésére semmiképp sem az egységes törzsszövetség, de nem is a teljes széttagoltság, hanem az egység és széttagoltság mértékének állandó változása volt jellemző. Tanshihuai törzsszövetsége nem a xianbeiek sztyeppei uralmának kezdete, csupán annak legegységesebb időszaka, ha úgy tetszik, csúcspontja.

\section{Hivatkozott szakirodalom}

Barfield, Thomas J. 1981. „The Hsiung-nu Imperial Confederacy: Organization and Foreign Policy." The Journal of Asian Studies 41.1: 45-61.

Barfield, Thomas J. 1992. The Perilous Frontier: Nomadic Empires and China, 221 BC to AD 1757. Cambridge \& Oxford: Blackwell.

Di Cosmo, Nicola 2004. China and its Ancient Enemies: The Rise of Nomadic Power in East Asian History. Cambridge: Cambridge University Press.

Ecsedy Ildikó 1979. „Törzs és törzsi társadalom a VI. századi türk birodalomban.” In: Nomádok és kereskedók Kína határain [Körösi Csoma Kiskönyvtár 16] Budapest: Akadémiai Kiadó, 165-197.

Gardiner, K. H. J. \& Crespigny de R. R .C. 1977. „T' an-shih-huai and the Hsien-pi Tribes of the Second Century A.D." Papers on Far Eastern History 15: 1-44.

Golden, Peter B. 1992. An Introduction to the History of the Turkic Peoples: Ethnogenesis and State-Formation in Medieval and Early Modern Eurasia and the Middle East. Wiesbaden: Harrassowitz.

Holocombe, Charles 2013. „The Xianbei in Chinese History.” Early Medieval China 19: 1-38. 
Kradin, Nikolai N. 2011. „The Stateless Empire: The Structure of the Xiongnu Nomadic Super-Complex Chiefdom.” In: Ursula Broasseder - Bryan K. Miller (eds.) Xiongnu Archaeology: Multidisciplinary Perspectives of the First Steppe Empire in Inner Asia. Bonn: Vor- und Frühgeschichtliche Archäologie, Rheinische Friedrich-WilhelmsUniversität Bonn, 77-96.

Lin Gan 林幹 1986. Xiongnu tongshi 匈奴通史 [„,A xiongnuk átfogó története"]. Beijing: Renmin Chubanshe.

Lin Gan 林幹1989. Donghu shi 東胡史 [A keleti barbárok története]. [Zhongguo gudai beifang minzu shicongshu]. Huhehaote: Neimenggu Renmin Chubanshe.

Ma Changshou 馬长寿1962. Wuhuan yu xianbei 乌桓与鲜卑 [A wuhuanok és a xianbeiek]. Shanghai Renmin Chubanshe.

Vásáry István 2003. A régi Belsó-Ázsia története [Magyar Őstörténeti Könyvtár 19.]. Budapest: Balassi Kiadó.

Scheidel, W. 2010. „The Xiongnu and the Comparative Study of Empire.” In: Ursula Broasseder - Bryan K. Miller (eds.) Xiongnu Archaeology: Multidisciplinary Perspectives of the First Steppe Empire in Inner Asia. Bonn: Vor- und Frühgeschichtliche Archäologie, Rheinische Friedrich-Wilhelms-Universität Bonn, 111-120.

Schreiber, G. 1947. „Das Volk der Hsien-pi zur Han-Zeit.” Monumenta Serica: The Journal of Oriental Studies 12.1: 145-203.

Yü, Ying-shih 2008a. „The Hsiung-nu.” In: Denis Sinor (ed.) The Cambridge History of Early Inner Asia. Cambridge: Cambridge University Press, 118-150. 
Yü, Ying-shih 2008b. „Han Foreign Relations.” In: Denis Twitchett and Michael Loewe (eds.) The Cambridge History of China Vol. 1. The Ch'in and Han Empires 221 B.C. - A. D. 220. Cambridge: Cambridge University Press, 377-462.

Zhou Weizhou 周伟洲 2015. „Wei-jin Nanbeichao shiqi beifang minzu yu minzu guanxi yanjiu 魏晋南北朝时期北方民族与民族关系研究 [,Északi népek és kapcsolataik a Wei-, a Jin-, illetve az Északi és Déli dinasztiák korában"]." Beifang Minzu Daxue Xuebao 北方民族大学 学报 126 [2015/6]: 5-14.

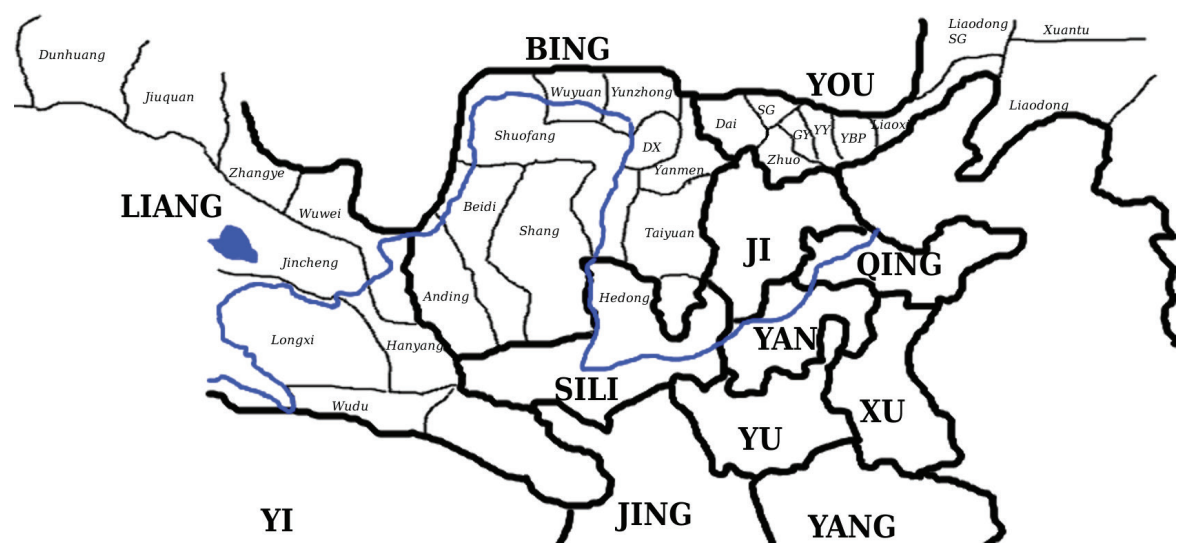

Kína északi határvidékének adminisztratív egységei i. sz. 140 körül.

A nagybetúk a tartományok, a kicsik a helyőrségek neveit jelölik.

Rövidítések:

SG - Shanggu (Liaodong SG- Liaodong Shuguo)

YBP - Youbeiping

YY - Yuyang

GY - Guangyang

DX - Dingxiang 